\title{
Stunting prevalence and its associated factors among children in primary school in Sidoarjo District: A secondary data analysis Prevalensi stunting dan faktor-faktor yang berhubungan dengan stunting pada anak Sekolah Dasar di Kabupaten Sidoarjo: Analisis data sekunder
}

\author{
Lini Anisfatus Sholihah ${ }^{1^{*}}$
}

\begin{abstract}
1 Program Studi Gizi, Fakultas Teknik, Universitas Negeri Surabaya, Jawa Timur, Indonesia. Email: $\underline{\text { linisholihah@gmail.com }}$

*Korespondensi:

Gedung A3, Program Studi Gizi Fakultas Teknik Kampus Universitas Negeri Surabaya, Jl. Ketintang, Kecamatan Gayungan, Kota Surabaya, Jawa Timur 6023, Jawa Timur, Indonesia. Email: linisholihah@gmail.com
\end{abstract}

\section{Riwayat Artikel:}

Diterima tanggal 28 Agustus 2020; Direvisi tanggal 29 Desember 2020; Disetujui tanggal 30 Juni 2021; Dipublikasi tanggal 30 Nopember 2021.

\section{Penerbit:}

Politeknik Kesehatan Aceh Kementerian Kesehatan RI

(c) The Author(s). 2021 Open Access

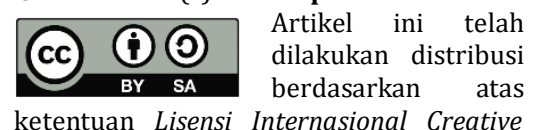
Commons Attribution 4.0

\begin{abstract}
Stunting is one under-nutrition condition that might be caused by inadequate nutrition consumption or frequent infection. Stunting prevalence in primary school-age children (PSAC) is still high in the third world and Indonesia. This present paper aimed to study the prevalence and the associated factors such as sex, school-area, and food intakes of stunting in PSAC in Sidoarjo, 2018. This study is crosssectional research using secondary data from baseline data of emotional demonstration projects in primary school students. Two hundred students were recruited from four schools representing urban and rural areas in Sidoarjo. Food intake was interviewed using SQ-FFQ. Children height was measured using microtoice. HAZ-score was calculated using WHO Anthro Plus software. Student t-test was done to test any differences in stunting prevalence between sex and school areas. The Chi-square test was used to check the difference in proportion for categories. Our results suggested the stunting prevalence among PSAC in Sidoarjo was $18 \%$ and was significantly greater in the rural area $(p=0,010)$. School location has association with stunting $(\mathrm{OR}=2,7 ; 95 \% \mathrm{CI} 1,25-5,8)$. In conclusion, we did not find any significant difference in food intakes, although stunted children were more likely to consume energy and carbohydrate. This condition must be considered to prevent obesity in stunted children.
\end{abstract}

Keywords: Food intake, primary school-aged children, rural, stunting, urban

\section{Abstrak}

Stunting merupakan salah satu kondisi kekurangan gizi yang dapat diakibatkan oleh konsumsi gizi yang tidak adekuat atau meningkatnya prevalensi penyakit prevalensi stunting pada anak sekolah masih cukup tinggi di negara berkembang, seperti di Indonesia. Studi ini mempelajari prevalensi stunting anak SD di Kabupaten Sidoarjo dan faktor-faktor yang berhubungan dengan stunting seperti jenis kelamin, area sekolah, dan asupan makanan. Penelitian menggunakan desain potong-lintang dengan data sekunder dari data baseline proyek Emotional Demonstration anak SD di Sidoarjo, tahun 2018. Sebanyak 200 siswa (usia 9-12 tahun) dari empat SD di Sidoarjo telah berpartisipasi. Asupan makanan didapatkan melalui interview $S Q-F F Q$. Tinggi badan diukur menggunakan microtoice. Skor-Z TB/U dihitung dengan menggunakan WHO Anthro Plus. Student-t-test digunakan untuk menguji perbedaan prevalensi stunting antara sex dan area. Uji Chisquare juga digunakan untuk menguji proporsi antar kategori. Hasil menunjukkan prevalensi stunting $18 \%$ pada anak SD secara keseluruhan. Prevalensi stunting di pedesaan lebih tinggi secara signifikan $(p=0,010)$. Sekolah di pedesaan berhubungan dengan stunting (OR=2,7; 95\%CI 1,25-5,8). Kesimpulan, tidak terdapat 
perbedaan signifikan pada asupan makanan, namun anak stunting cenderung mengonsumsi asupan energi dan karbohidrat yang lebih tinggi. Kondisi ini perlu diperhatikan untuk mencegah obesitas pada anak stunting.

Kata Kunci: Anak usia sekolah dasar, asupan makanan, perdesaan, perkotaan, stunting

\section{Introduction}

Stunting is a condition in which children's height is more than two standard deviations below the median determined by World Health Organization (WHO) Child Growth Standards (WHO, 2014). Stunting that occurs during childhood has adverse effects on cognitive performance (Asmare et al., 2018), immune function (Bourke et al., 2016), and is negatively associated with a mathematic score in school (Haile et al., 2016). Later in adulthood, stunting was negatively associated with work productivity in men and reproductive health in women as its long-term consequences (Dewey \& Begum, 2011).

Whereas stunting in under five received much attention from previous studies (Rachmi et al., 2016; Ramli et al., 2009; Utami et al., 2019) in Indonesia, only a little research focused on primary school-age children (PSAC) could be documented. PSAC is vulnerable to stunting because of poor diet (Getaneh et al., 2019), urban vs. rural areas disparities, and sex (Akram et al., 2018). Stunting in PSAC typically also results from a cumulative growth flattering process that formerly occurs at the very early life (Getaneh et al., 2019).

It was reported that the prevalence of stunting among PSAC differs across the country and area. In India, the overall stunting prevalence in PSAC ranged from $4.47 \%$ to 19.2\% (Pal \& Kanungo, 2016; Pradhan et al., 2020; Yadav et al., 2016). In Ethiopia, the prevalence of stunting was even higher, ranging between $8,9 \%$ and $41.9 \%$ (Degarege et al., 2015; Mesfin et al., 2015; Tariku et al., 2018). When it takes on developed countries such as China, the stunting prevalence was lower than other countries, only 2,3\% (Song et al., 2019).

In Indonesia, several works examining stunting prevalence among PSAC were established. A study conducted in Riau Province found that the stunting prevalence was $21,4 \%$ (Ernalia et al., 2018). Another large study, which represented eight provinces in Indonesia, suggested that the prevalence of stunting among PSAC was 28\% (Yasmin et al., 2019).

Given the above situation, this present paper aimed to measure the prevalence of stunting in PSAC, in which the national data in Indonesia is still scarce. We chose Sidoarjo district as a location because, according to the Basic Health Survey 2018, the stunting prevalence of under-five in Sidoarjo was almost similar to the overall province's (MoH RI, 2018b). Thus, we expect the same condition to apply for PSAC and represent a picture of stunting prevalence in East Java Province. Furthermore, we would examine the association between food intake, sex, and school area on stunting prevalence.

\section{Method}

This study is cross-sectional research using secondary data from baseline data of emotional demonstration projects in primary school students.

We conducted secondary data analyses derived from the baseline data of the Emo-Demo project carried out by the Nutrition Laboratory Technical Implementation Unit of East Java Provincial Health Office in February 2018. This project was an annual project funded by the East Java Provincial Government Budgeting or APBD to improve the school-aged children knowledge and awareness regarding breakfast importance, snack preference, and sanitation by using the emotional demonstration (Emo-Demo) method developed by GAIN (Videricka et al., 2020).

The project was conducted in Sidoarjo District, East Java Province. One hundred students were representing primary government schools in each rural and urban area in Sidoarjo. Two public schools in Wonoayu (rural area) and two other public schools in Sukodono (urban area) were selected according to Dinas Kesehatan Sidoarjo appointment. Each school consisted of 
50 respondents. Students from 4th until 5th grade (aged 9-12 years old) were included. The inclusion criteria were healthy during the data collection, and their parents signed an informed consent form. Altogether 200 respondents have participated.

Food intakes (energy and macronutrients) were interviewed by trained enumerators, a technical dietitian, using a semi-quantitative food frequency questionnaire (SQ-FFQ). The food intakes' energy, carbohydrate, protein, and fat contents were computed using Nutrisurvey software. The size of the food portion was estimated into household portions. Food picture books were used to help the respondents estimate the food portion and to reduce bias. The Ministry of Health previously developed the picture book, Republic of Indonesia.

The height of students was measured using a microtoice. WHO Anthro Plus calculated Heightto-age Z-score (HAZ) score. Children were categorized into three categories: 1) normal if HAZ score $\geq-2$ SD; 2) stunted if HAZ score <-2 SD, and 3 ) severely stunted if the score was <-3 SD.

Both height and food intake data were presented descriptively in mean \pm standard deviation (SD). We used an independent student ttest to check the differences in energy and macronutrient intakes between stunted and nonstunted groups. Chi-square test, including odds ratios (OR), was calculated to test whether stunted children proportion was different by sex and school area. P-value of $<0,05$ was regarded as significant. All statistics were done using SPSS software.

\section{Results and Discussion}

The respondents analyzed in this present study were 9-12 years old (mean $=11$ years old). Respondents were 101 males and 99 females. Overall, the prevalence of stunting among our respondents was $18 \%$ (see table 1 ). A $4 \%$ of the respondent was severely stunted. The mean HAZ-score was reported as $-0,91$ $( \pm 1,03)$.

Table 1. Respondent distribution into normal, stunting, and severely stunted

\begin{tabular}{lcc}
\hline \multirow{2}{*}{ Category of HAZ } & \multicolumn{2}{c}{ Number of } \\
& \multicolumn{2}{c}{ respondents (n) } \\
\cline { 2 - 3 } & $\mathrm{n}$ & $\%$ \\
\hline Normal & 164 & 82 \\
Stunted & 28 & 14 \\
Severely stunted & 8 & 4 \\
\hline
\end{tabular}

Next, we did chi-square to test the association between stunting proportion on sex and school areas. As depicted in table 2, male children had a lower relative risk for being stunted compared to female children $(\mathrm{OR}=0,85)$, although the proportion was not significantly different (p-value $>0,05$ ). Furthermore, we observed that stunting was more common in children from rural areas than in urban areas, and the difference was significant ( $p$-value $<0,010$ ). We suggested that students in the rural had almost triple the risk to be stunted compared to PSAC in an urban area $(\mathrm{OR}=2,7)$.

Table 2. Stunting prevalence among primary school children according to sex and school area

\begin{tabular}{llccccc}
\hline \multirow{2}{*}{ Variables } & & \multicolumn{2}{c}{ Stunted } & \multirow{2}{*}{ Total } & \multirow{2}{*}{ Odds Ratio (95\%) } & \multirow{2}{*}{ P-value } \\
\cline { 3 - 4 } & & Yes $(\%)$ & No $(\%)$ & & & \\
\hline \multirow{3}{*}{ Sex } & Male & $17(8,0)$ & $84(42,0)$ & 101 & $0,85(0,41-1,76)$ & 0,664 \\
& Female & $19(10,0)$ & $80(40,0)$ & 99 & & \\
& Rural & $25(12,0)$ & $75(38,0)$ & 100 & $2,7(1,25-5,8)$ & $0,010^{*}$ \\
& Urban & $11(6,0)$ & $89(44,0)$ & 100 & & \\
\hline Total & & $36(28,0)$ & $164(82,0)$ & 200 & & \\
\hline
\end{tabular}

${ }^{*}$ P-value was derived from the student $t$-test. P-value is significant at $<0,05$

We then analyzed the food intakes, including energy, protein, fat, and carbohydrate intakes, according to stunted and non-stunted groups, to see whether there was any significant difference in food intakes. As shown in table 3 , our results showed slightly and non-significant higher energy intake (1.705 kcal vs. $1.688 \mathrm{kcal})$ and carbohydrate intake $(240$ grams vs 233 grams) in the stunted children. The protein and fat intakes are almost similar in both groups. 
Table 3. Energy and macronutrient intakes among stunted and non-stunted children

\begin{tabular}{lcccc}
\hline \multirow{2}{*}{$\begin{array}{l}\text { Energy and macronutrient } \\
\text { intakes }\end{array}$} & \multicolumn{2}{c}{ Stunted status } & \multirow{2}{*}{ P-value } \\
\cline { 2 - 4 } & Yes (Mean \pm SD) & No (Mean \pm SD) & $\Delta$ Mean \pm SD & \\
\hline Energy (kcal) & $1.705 \pm 455$ & $1.688 \pm 485$ & $17 \pm 30$ & 0,864 \\
Protein (g) & $55 \pm 18$ & $56 \pm 21$ & $1 \pm 3$ & 0,805 \\
Fat (g) & $59 \pm 18$ & $60 \pm 19$ & $1 \pm 1$ & 0,772 \\
Carbohydrate (g) & $240 \pm 82$ & $233 \pm 74$ & $7 \pm 8$ & 0,655 \\
\hline
\end{tabular}

${ }^{*}$-value was derived from student $t$-test

Stunting remains a major public health problem that still occurs in Indonesia. Stunting could lead to adverse health and cognitive and work performance consequences later in life (Asmare et al., 2018; Bourke et al., 2016; Dewey \& Begum, 2011; Haile et al., 2016). Studies also confirmed that stunting was associated with mortality (Mcdonald et al., 2013). By considering the burden of, WHO then endorsed a classification of stunting prevalence into four quartiles, namely 1) low ( $<20 \%), 2$ ) medium (20$39 \%), 3$ ) high (30-39\%), and 4) very high ( $\geq$ $40 \%$ ) (Onis et al., 2018).

While stunting among under-five children in Indonesia reached 19,3\% in 2018 (MoH RI, 2018a), little is known regarding stunting prevalence among Indonesian primary schoolage children (PSAC). This present study showed that the overall prevalence of stunting was $18 \%$ among PSAC in Sidoarjo District. This prevalence was similar to other studies obtained from Nigeria ( $n=245$, aged $10-14$ years), which was 19,6\% (Senbanjo et al., 2011), in Egypt $(n=396$, aged 10-11 years), which was 17,9\% (El-fatah \& Abu-elenin, 2019), and in Aceh Indonesia ( $\mathrm{n}=$ 201, aged 9-12 years) which was 20,4\% (Dimiati \& Hajar, 2019), but was lower compared to a study conducted in Riau ( $\mathrm{n}=299$, aged 5-14 years) where the prevalence was 28\% (Ernalia et al., 2018). The discrepancy between our result and the study in Riau might be due to the different range of age, in which it used a more comprehensive age range than us. When referring to the prevalence threshold of stunting, our study indicated that the stunting prevalence in PSAC in Sidoarjo was categorized into the low quartile.

Studies have focused on the relationship between sex on stunting within PSAC, although the results were inconsistent. While several studies confirmed that stunting was more prevalent in male students than females (Batool et al., 2012; Ghaida Yasmin, 2014), another study reported the reversed result (Lestari et al., 2018), and others showed no major difference (Bogale et al., 2018; Mesfin et al., 2015). In this present study, we confirmed that sex had no association with stunting in PSAC.

Interestingly, we reported that children from the rural school were at heightened risk to be stunted. This present result was in line with other studies conducted in Egypt (El-fatah \& Abu-elenin, 2019), Nigeria (Oninla et al., 2007), and Indonesia (Yasmin et al., 2019; Al Rahmad et al., 2020). This evidence might be due to the higher prevalence of intestinal parasites in a rural population that could cause infection and disturb the linear growth. In addition, there might be a gap in social-economic status and feeding practices between rural and urban communities that could affect food purchasing and limit some nutritious foods such as animal protein (Khuwaja et al., 2005). Unfortunately, we did not measure those possible causes in this report. Therefore, we recommended future works to confirm this.

UNICEF (1990) conceptual framework of malnutrition mentioned diet as one factor influencing malnutrition (UNICEF, 1997). In this current study, we could not see any statistical difference in energy intake and macronutrient intakes between stunted and non-stunted PSAC groups. The amount of energy and carbohydrate intakes were slightly higher in the stunted group. This finding did not meet our expectations.

It is interesting to note that we found a study whose result was similar to ours. The previous research worked in PSAC in Brazil and found that stunted children tend to overeat compared to non-stunted. The results showed that energy intake in stunted children was higher $(p=0,120)$. Moreover, when they calculated the energy intake per kg body weight, statistics showed a significant difference between groups. Stunted children had significantly greater energy intake per kg body weight than the non-stunted group 
(Hoffman et al., 2000). A possible explanation is present for the effect of stunting on energy and carbohydrate intakes regulation. Malnutrition in early life was associated with an impairment in fat oxidation. When fat oxidation is impaired, carbohydrate oxidation will increase, causing a depletion in carbohydrate stores and increased hunger (Hoffman et al., 2000; Sawaya et al., 2004). This phenomenon should be considered since overeating or hyperphagia was common in stunted children and could increase obesity in stunted children as a consequence.

Another possible explanation regarding our result was the previous cumulative growth impairment occurring in the early life that resulted in stunting conditions in the PSAC. This growth impairment still existed in the school-age and resulted in stunting conditions. This stunting condition would worsen at an older age and lead into short adulthood later in life (Getaneh et al., 2019).

The disadvantage of this present study was the use of secondary data collection. The selections of schools and students might be based on convenience. Thus, it is important to note that the respondents in this present paper might not represent school-aged children in Sidoarjo.

\section{Conclusion}

In conclusion, we demonstrated that the stunting prevalence among PSAC in Sidoarjo was still in the low quartile. Schooling in the rural area showed to be the only factor associated with stunting in children. Overeating in stunted children was observed and must be considered carefully to prevent the other obese-stunted condition.

Our findings suggested that school-aged children in a rural areas should receive more attention to improve their nutritional status.

\section{Acknowledgement}

We acknowledge the East Java Provincial Government Budgeting for funding the Emotional and Demonstration project implementation and Nutrition Laboratory Technical Implementation Unit of East Java Provincial Health Office, who provided us with the secondary data for our study analyses.

\section{References}

Akram, R., Sultana, M., Ali, N., Sheikh, N., \& Sarker, A. R. (2018). Prevalence and determinants of stunting among preschool children and its urban-rural disparities in Bangladesh. Food and Nutrition Bulletin, 39(4), 521-535. https://doi.org/10.1177/03795721187947 70

Al Rahmad, A. H., Miko, A., Labatjo, R., Fajriansyah, F., Fitri, Y., \& Suryana, S. (2020). Malnutrition prevalence among toddlers based on family characteristics: A cross-sectional study in the rural and urban areas of Aceh, Indonesia. Sri Lanka Journal of Child Health, 49(3), 263. https://doi.org/10.4038/sljch.v49i3.9145

Asmare, B., Taddele, M., Berihun, S., \& Wagnew, F. (2018). Nutritional status and correlation with academic performance among primary school children, northwest Ethiopia. BMC Research Notes, 11(1), 1-6. https://doi.org/10.1186/s13104-0183909-1

Batool, S., Shaheen, A., Rehman, R., Qamar, S., Raza, S. M. A., Jabeen, R., \& Nisa, F. U. (2012). To assess the nutritional status of primary school children in an urban school of faisalabad. Pakistan Journal of Medical and Health Sciences, 6(3), 776-778.

Bogale, T. Y., Bala, E. T., Tadesse, M., \& Asamoah, B. 0. (2018). Prevalence and associated factors for stunting among 6-12 years old school age children from rural community of Humbo district, Southern Ethiopia. BMC Public Health, 18(1), 1-8. https://doi.org/10.1186/s12889-0185561-z

Bourke, C. D., Berkley, J. A., \& Prendergast, A. J. (2016). Immune dysfunction as a cause and consequence of malnutrition. Trends in Immunology, 37(6), 386-398. https://doi.org/10.1016/j.it.2016.04.003

Degarege, D., Degarege, A., \& Animut, A. (2015). Undernutrition and associated risk factors among school age children in Addis Ababa, Ethiopia Global health. BMC Public Health, 15(1), 1-9. https://doi.org/10.1186/s12889015-1714-5

Dewey, K. G., \& Begum, K. (2011). Long-term consequences of stunting in early life. Maternal and Child Nutrition, 7(SUPPL. 3), 5-18. https://doi.org/10.1111/j.1740- 
8709.2011.00349.x

Dimiati, H., \& Hajar, S. (2019). The correlation between stunting and learning achievement in 9-12 years old children at Idi Rayeuk, East Aceh Regency, Indonesia. Ournal of Medical Practice and Review, 3(5), 539-544.

El-fatah, N. K. A., \& Abu-elenin, M. M. (2019). Prevalence of stunting, overweight and obesity among Egyptian primary school children in Behera Governorate. Food Public Health, 9(3), 84-93. https://doi.org/10.5923/j.fph.20190903.02

Ernalia, Y., Dwi Utari, L., \& Restuastuti, T. (2018). Different intakes of energy and protein in stunted and non-stunted elementary school children in Indonesia. KnE Life Sciences, 4(4), 556-562. https://doi.org/10.18502/kls.v4i4.2318

Getaneh, Z., Melku, M., Geta, M., Melak, T., \& Hunegnaw, M. T. (2019). Prevalence and determinants of stunting and wasting among public primary school children in Gondar town, northwest, Ethiopia. BMC Pediatrics, 19(1), 1-11. https://doi.org/10.1186/s12887-0191572-x

Ghaida yasmin, lilik kustiyah and C. M. D. (2014). PH 350 Undernutrition Risks Indonesia (pp. 557-566).

Haile, D., Nigatu, D., Gashaw, K., \& Demelash, H. (2016). Height for age $\mathrm{z}$ score and cognitive function are associated with academic performance among school children aged 811 years old. Archives of Public Health, 74(1), 1-7. https://doi.org/10.1186/s13690-0160129-9

Hoffman, D. J., Roberts, S. B., Verreschi, I., Martins, P. A., De Nascimento, C., Tucker, K. L., \& Sawaya, A. L. (2000). Regulation of energy intake may be impaired in nutritionally stunted children from the shantytowns of Sao Paulo, Brazil. Journal of Nutrition, 130(9), 2265-2270. https://doi.org/10.1093/jn/130.9.2265

Khuwaja, S., Selwyn, B. J., \& Shah, S. M. (2005). Prevalence and correlates of stunting among primary school children in rural areas of southern Pakistan. Journal of Tropical Pediatrics, 51(2), 72-77. https://doi.org/10.1093/tropej/fmh067

Lestari, S., Fujiati, I. I., Keumalasari, D., \& Daulay, M. (2018). The prevalence and risk factors of stunting among primary school children in North Sumatera, Indonesia. IOP Conference Series: Earth and Environmental Science, 125(1), 012219. https://doi.org/10.1088/17551315/125/1/012219

Mcdonald, C. M., Olofin, I., Flaxman, S., Fawzi, W. W., Spiegelman, D., \& Caulfield, L. E. (2013). The effect of multiple anthropometric deficits on child mortality: meta-analysis of individual data in 10 prospective studies from. The American Journal of Clinical Nutrition, 2, 896-901. https://doi.org/10.3945/ajcn.112.047639 .INTRODUCTION

Mesfin, F., Worku, A., \& Birhane, Y. (2015). Prevalence and associated factors of stunting among primary school children in Eastern Ethiopia. Nutrition and Dietary Supplements, 61. https://doi.org/10.2147/nds.s80803

MoH RI. (2018a). Main results of Basic Health Research (Riskesdas) 2018, Indonesia.

MoH RI. (2018b). Main results of Basic Health Research (Riskesdas) 2018 in East Java Province.

Oninla, S. O., Owa, J. A., Onayade, A. A., \& Taiwo, 0. (2007). Comparative study of nutritional status of urban and rural Nigerian school children. Journal of Tropical Pediatrics, 53(1), $39-43$. https://doi.org/10.1093/tropej/fml051

Onis, M. De, Borghi, E., Arimond, M., Webb, P., Croft, T., Saha, K., De-regil, L. M., Thuita, F., Heidkamp, R., Krasevec, J., Hayashi, C., \& Flores-ayala, R. (2018). Prevalence thresholds for wasting, overweight and stunting in children under 5 years. Public Health Nutrition, 22(1), 175-179. https://doi.org/10.1017/S136898001800 2434

Pal, D., \& Kanungo, S. (2016). Malnutrition scenario among school children in EasternIndia-an epidemiological study. Epidemiology: Open Access, 06(02), 1-9. https://doi.org/10.4172/21611165.1000228

Pradhan, D., Biswasroy, P., Naik, K., Ghosh, G., \& Rath, G. (2020). A review of current interventions for COVID-19 prevention. Archives of Medical Research, January. https://doi.org/10.1016/j.arcmed.2020.0 4.020 
Rachmi, C. N., Agho, K. E., Li, M., \& Baur, L. A. (2016). Stunting, underweight and overweight in children aged 2.0-4.9 years in Indonesia: Prevalence trends and associated risk factors. PLoS ONE, 11(5), 1-17. https://doi.org/10.1371/journal.pone.0154 756

Ramli, Agho, K. E., Inder, K. J., Bowe, S. J., Jacobs, J., \& Dibley, M. J. (2009). Prevalence and risk factors for stunting and severe stunting among under-fives in North Maluku province of Indonesia. BMC Pediatrics, 9(1), 64. https://doi.org/10.1186/1471-24319-64

Sawaya, A. L., Martins, P. A., Grillo, L. P., \& Florêncio, T. T. (2004). Long-term effects of early malnutrition on body weight regulation. Nutrition Reviews, 62(7), 127133. https://doi.org/10.1111/j.17534887.2004.tb00082.x

Senbanjo, I. O., Oshikoya, K. A., Odusanya, O. O., \& Njokanma, O. F. (2011). Prevalence of and risk factors for stunting among school children and adolescents in Abeokuta, Southwest Nigeria. Journal of Health, Population and Nutrition, 29(4), 364-370. https://doi.org/10.3329/jhpn.v29i4.8452

Song, Y., Agardh, A., Ma, J., Li, L., Lei, Y., Stafford, R. S., \& Prochaska, J. J. (2019). National trends in stunting, thinness and overweight among Chinese school-aged children, 1985-2014. International Journal of Obesity, 43(2), 402-411. https://doi.org/10.1038/s41366-0180129-7

Tariku, E. Z., Abebe, G. A., Melketsedik, Z. A., \& Gutema, B. T. (2018). Prevalence and factors associated with stunting and thinness among school-age children in Arba Minch Health and Demographic Surveillance Site, Southern Ethiopia. PloS One, 13(11), e0206659. https://doi.org/10.1371/journal.pone.020 $6659 \mathrm{LK}$

UNICEF. (1997). Causes of child malnutrition. United Nations Children's Fund.

Utami, R. A., Setiawan, A., \& Fitriyani, P. (2019). Identifying causal risk factors for stunting in children under five years of age in South Jakarta, Indonesia. Enfermeria Clinica, July. https://doi.org/10.1016/j.enfcli.2019.04.093

Videricka, E. M., Ningtyias, F. W., Astuti, N. F. W., \& Adi, D. I. (2020). Emotional demonstration (Emo-Demo) katakan tidak pada Makanan Pendamping Air Susu Ibu (MP-ASI) dini. Al-Khidmah, 3(1), 19. https://doi.org/10.29406/alkhidmah.v3i1.2401

WHO. (2014). WHA global nutrition targets 2025: Stunting policy brief. In WHO/NMH/NHD/14.3: Vol. 14.3 (Issue WHO/NMH/NHD/14.3, pp. 1-10).

Yadav, A., Kotwal, A., Vaidya, R., \& Yadav, J. (2016). Anthropometric indices and its sociodemographic determinants among primary school children of an urban school in Pune, India. International Journal of Medicine and Public Health, 6(4), 160-164. https://doi.org/10.5530/ijmedph.2016.4.3

Yasmin, G., Kustiyah, L., \& Dwiriani, C. M. (2019). Stunted Children Has Higher Risk of Overweight: A Study on Children Aged 6-12 Years in Eight Provinces in Indonesia. Pakistan Journal of Nutrition, 18(5), 455-463. https://doi.org/10.3923/pjn.2019.455.463 